\title{
RESENSI
}

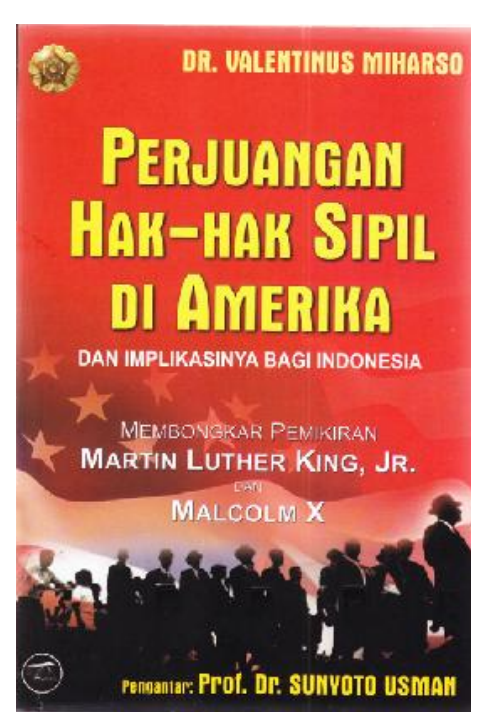

\section{PERJUANGAN MEMERDEKAKAN KAUM TERTINDAS: BELAJAR DARI MARTIN LUTHER KING, JR DAN MALCOLM $X$}

Judul Buku
Pengarang
Penerbit
Tahun
Tebal Halaman
Zuly Qodir*)

Amerika, negara adi daya yang mengklaim paling demokratis ternyata memiliki beberapa keburukan substansial. Bukan saja secara konseptual, tetapi dalam praktik politik, Amerika ternyata menyimpan persoalan sangat serius. Sayangnya jarang dikemukakan pada publik oleh pemerintahan Amerika maupun para pengamat dan sekaligus pemuka Negeri Paman Sam tersebut. Kebobrokan Amerika tertutup dengan kampanye yang sangat besar dan sistematik tentang kehebatan Amerika membantu negara lain atau memprovokasi negara lain untuk berbuat yang Amerika kehendaki.

Hal seperti itu jelas memberikan koreksi yang fundamental pada negeri adi daya tanpa tanding di muka bumi ini. Apa yang dilakukan dan dikampanyekan Amerika mampu menyihir masyarakat dunia. Masyarakat dunia bak tak memiliki kekuatan apa pun berhadapan dengan kampanye Amerika. Dari dulu sekurang-kurangnya telah berjalan dalam kurun waktu ke-43 kepresidenan negeri yang mendapuk dirinya sebagai kampiun demokrasi.

Tentu saja kita bisa berdebat keras soal apakah benar Amerika adalah negeri demokratis di mana salah satu unsur fundamentalnya adalah adanya penghormatan hak-hak kaum minoritas etnis, minoritas agama maupun minoritas kelas sosial. Kita juga bisa berdebat apakah Amerika sudah menghilangkan perilaku politik dan kultur diskriminatif dalam bermasyarakat dan bernegara, serta apakah Amerika benarbenar ideal sebagai contoh dalam praktik politik yang berkeadaban (yang dicirikan dengan penghargaan atas keragaman etnis dan keragaman ras)?

Persoalan-persoalan diskriminasi etnis yang dilakukan Amerika dengan cukup baik disampaikan oleh penulis buku Perjuangan Hak-Hak Sipil di Amerika, Membongkar Pikiran Martin Luther King, Jr dan Malcolm

*) Zuly Qodir, Sosiolog, Alumni Sekolah Pascasarjana Universitas Gadjah Mada. Mengajar di Program Doktor Sosiologi UGM, Fakultas Ilmu Sosial dan Ilmu Politik Universitas Muhammadiyah Yogyakarta, dan Magister Perdamaian dan Resolusi Konflik UGM. 
X, Valentinus Miharso, dalam studi yang ditulisnya pada Program Pascasarjana Universitas Gadjah Mada Fakultas Ilmu Budaya. Valentinus Miharso memiliki penglihatan dan pengamatan yang "cermat" jeli dan kritis sehingga tidak menempatkan Amerika "serba luar biasa", tetapi sekaligus menghadirkan kritik tajam atas perlakuan terhadap kaum kulit hitam yang sering disebut dan diasosiasikan dengan "negro".

Miharso dengan mendasarkan pada pemikiran Martin Luther King, Jr dan Malcolm X memberikan penjelasan pada publik bahwa Amerika pernah menjalani kehidupan politik dan kultural yang diskriminatif, sehingga jelas tidak sesuai dengan prinsip demokrasi yang Amerika Serikat kampanyekan, yakni kesetaraan dan penghormatan atas hak-hak warga negara sipil. Warga negara Negro adalah contoh yang paling jelas mendapatkan perlakuan diskriminatif oleh rezim politik dan kultur Amerika selama bertahun-tahun sehingga perlu dipersoalkan serius.

Dua tokoh yang dijadikan rujukan (kajian) Miharso, Martin Luther King, Jr dan Malcolm X merupakan aktor-aktor yang memberikan perhatian pada perjuangan menempatkan kaum negro dan kulit hitam pada posisi "sederajat" dengan kaum kulit putih Amerika. Kaum kulit hitam selama bertahun-tahun berada dalam posisi sangat marginal, terpinggir dan tak dimanusiawikan. Warga negara kulit hitam diperlakukan semena-mena, penuh dengan kekerasan, penuh dengan penghinaan, dan penuh dengan tipu muslihat serta kebohongan-kebohongan sehingga warga kulit hitam tempatnya tidak lain kecuali "di pinggiran". Warga kulit hitam tempatnya adalah "buritan" yang menyakitkan.

\section{Dimulai dari diri sendiri}

Memperhatikan kondisi semacam itu, Martin Luther King, Jr sebagai seorang yang berdarah ningrat, berpendidikan tidak tinggal diam, sekalipun dia sendiri sebenarnya tidak termasuk golongan kulit hitam, tetapi golongan kulit putih. Martin Luther King,
Jr berasal dari kelompok borjuis, tetapi tidak kemudian menikmati borjuasi yang telah diperolehnya dengan semena-mena sebagaimana banyak kaum borjuis yang berlaku semena-mena kepada rakyatnya atau kepada mereka yang dianggap "kere" dan marginal apalagi pengabdinya.

Sedikit berbeda dengan Martin Luther King, Jr, Malcolm X adalah bagian dari masyarakat warga kulit hitam yang selama ratusan tahun tertindas di Amerika. Malcolm X, sebagai bagian dari warga kulit hitam melihat apa yang terjadi pada masyarakatnya merupakan sesuatu yang tidak boleh dibenarkan dan terus berlangsung. Apa yang terjadi pada kelompok warga kulit hitam harus berakhir dan berobah sehingga warga kulit hitam tidak selalu dalam posisi pinggiran dan negatif. Semuanya tidak bisa berubah jika tidak ada niat serius untuk melakukan perubahan tersebut. Perubahan akan terjadi jika di mulai dari diri sendiri sebab itulah kekuatan perobahan yang internal adalah energy paling dahsyat untuk sebuah kebijakan politik.

Hal yang menarik dari Martin Luther King, Jr dan Malcolm X adalah melakukan perubahan bukan karena dirinya teraniaya dan tersandra secara politik maupun ekonomi. Sekalipun dirinya "terbebas" dari Sandra politik dan ekonomi bahkan kultur, tetapi semangat merombak masyarakat tetap muncul dengan berkobar.

Hal seperti itu yang kadang kurang berkembang di Indonesia. Perubahan hanya dilakukan oleh mereka yang merasa tertindas, teraniaya, terpinggir tetapi bukan oleh mereka yang "menikmati penindasan" bahkan penopang rezim penindas dan pengeruk uang rakyat. Hal ini yang membuat perubahan di Indonesia berjalan lambat, bahkan sangat lambat sebab terhalang tembok besar bernama para kroni kekuasaan yang despotik dan penindas rakyat.

Kita memang harus bekerja keras menghapus penindasan atas bangsanya sendiri oleh bangsanya sendiri bukan oleh orang lain. Jika orang lain menindas memang dengan mudah kita melakukan perlawanan, 
tetapi jika penindasnya adalah kawan dan kelompok bangsa sendiri seringkali kita turut memberikan dukungan dengan cara tidak memberikan kritik, berpura-pura tidak tahu bahkan turut menikmatinya karena merasa mendapatkan untung dari penindasan yang dilakukan pada kelompok lain.

\section{Melihat realitas objektif}

Perubahan harus berjalan dalam rel yang sesuai dan mendasarkan pada realitas objektif yang kita lihat. Bukan saja yang kita alami, tetapi orang lain juga alami dan sementara kita melihatnya pun harus kita lakukan perubahan. Itulah yang dilakukan Martin Luther King, Jr dan Malcolm X melihat penindasan atas kaum kulit hitam Amerika oleh kulit putih dan kebijakan Negara. Dua tokoh perubahan tidak secara langsung mendapatkan perlakukan diskriminatif, tetapi melihat realitas objektif yang tidak bisa dibiarkan dan berlangsung terusmenerus.

Membangun perubahan tidak efektif jika hanya sendirian alias solo karir. Perubahan membutuhkn dukungan yang kuat dari banyak pihak. Perubahan yang cepat dan mendasar akan berjalan jika ada topangan politik, aktif banyak bergerak, memiliki jaringan, dan program yang jelas sehingga tidak berjalan di tempat alias tidak ada progresivitas. Oleh karena itu, membangun kekuatan pendobrak sebagai kekuatan sentral perubahan harus dilakukan seksama tidak boleh main-main.

Jaringan perubahan, aktor, dan program perubahan harus tersusun sistematik sehingga mudah melakukan pengukuran dan koreksi atas apa yang terjadi selama perubahan dilakukan. Aktor yang kuat dibutuhkan karena akan memberikan payung dan arah ketika kondisi chaotic, sebab seringkali perubahan menimbulkan situasi chaotic sehingga pemimpin yang kuat dan kharismatik dibutuhkan agar tidak gagap dan gagal melakukan perubahan ke depan yang lebih baik dari masa sebelumnya.
Dalam merefleksikan aktivitas yang telah dilakukan merupakan keharusan yang tidak boleh ditawar-tawar agar tidak lupa diri. Ini sekaligus semacam otokritik atas apa yang dilakukan dalam membuat perubahan dan mengawal perubahan yang kita kehendaki. Merefleksikan aktivitas masa lalu dan menuju aktivitas masa depan adalah prasyarat utama dalam sebuah gerakan sosial yang membutuhkan kesinambungan program, aktor, dan jaringan sosial tanpa batasan wilayah geografik.

Untuk mempercepat dan mempermudah perjalanan perubahan, menggerakkan sistem kultural dan politik adalah prasyarat lain yang tidak boleh dilewatkan. Perubahan kultural merupakan prasyarat untuk melakukan kritik atas perilaku kultural yang dilakukan masyarakat sipil dan masyarakat politik yang dianggap "biasa" dengan penindasan yang selama ini dilakukan. Hal yang dianggap "biasa" harus dihilangkan sehingga ada perubahan kultural dan itulah yang harus dimulai dari perubahan habitus sosial.

Perubahan politik membutuhkan perubahan sistem politik, yaitu politicall will pemerintah dan pelaku politik bangsa. Pemimpin yang bervisi dan bermartabat, menjunjung politik yang bersih, bebas Kolusi Korupsi dan Nepotisme (KKN) adalah syarat utama dalam perubahan politik nasional maupun politik kebangsaan.

Apa yang dilakukan oleh Martin Luther King dan Malcolm X dengan melakukan perubahan kultural dan politik di Amerika akhirnya membuahkan hasil sehingga sekalipun belum seratus persen warga kulit hitam mendapatkan "tempat yang layak", maka telah terjadi perubahan besar-besaran dalam sistem kultural dan politik Amerika di bawah Presiden Bill Clinton dan sekarang berharap pada Presiden Barack Obama. Bagaimana dengan Indonesia? Kita lihatlah realitas bangsa dengan kritis dan ketenangan, sudahkah terjadi perubahan signifikan dengan apa yang dinamakan reformasi politik dan kultural? 


\section{Pelajaran untuk Indonesia}

"Kita kaum pribumi (boemi poetra) dianggap seperempat manusia oleh kaum kulit putih (bangsa Eropa), kolonialis yang menghisap darah, daging, dan susu kita! Bangsa pribumi dianggap tidak layak mendapatkan kesejahteraan. Tidak layak mendapatkan penghormatan dan tidak layak mendapatkan kemerdekaaan! Akankah kita terus menderita dalam kepalan kaum kolonialis? Tentu tidak! Kita harus bersatu, bangkit dan menghilangkan segala bentuk penindasan kaum pribumi!, demikian pidato HOS. Tjokroaminoto pada Rapat Akbar Sarekat Islam di Surabaya tahun 1924, yang disambut gemuruh peserta Rapat Akbar Sarekat Islam.

Apa yang terjadi pada kaum kulit hitam Amerika dalam beberapa hal sama dengan yang terjadi di Indonesia. Penindasan fisik, penindasan struktural, penindasan kultural, dan penindasan keimanan berlangsung sangat lama, sepanjang Indonesia merdeka ke-66 tahun lamanya. Penindasan memang tidak selalu datang dari bangsa lain, tetapi datang pula dari bangsanya sendiri yang memperlakukan warganya secara tidak manusiawi. Sesama warga negara memperlakukan warga lainnya dengan cara-cara yang tidak beradab, menggunakan kekerasan, mengusir, membunuh maupun merusak tempat-tempat yang digunakan sebagai sarana kaum yang berbeda dengan pandangannya.

Pluralisme SARA di Indonesia bukan hanya sebuah keniscayaan hidup dan dasardasar kenegaraan, tetapi pluralisme SARA adalah keharusan dalam politik dan kultural karena itu harus menjadi pandangan hidup dan perilaku politik kebangsaan agar bangsa ini tidak bercerai berai dan akhirnya tinggal kenangan sejarah masa lampau yang menyedihkan. Indonesia adalah pluralis dalam segi SARA sekaligus kultur. Hal ini tidak bisa diremehkan.

Jika bangsa ini merehkan pluralisme SARA dan kultur Indonesia, apa yang terjadi di Uni Soviet bukan tidak mungkin menimpa negeri beribu-ribu pulau dan suku- etnis yang bertebaran di seantero jagad nusantara. Ribuan pulau dan ratusan etnis harus dijaga menjadi kesatuan sehingga Indonesia tetap menjadi Indonesia yang pluralistik, Bhinneka Tunggal Ika, bukan Homogenisasi dan uniformitas. Proses politik homogenisasi dan uniformisasi harus dihilangkan dari jagad Republik ini. Kita harus jaga Indonesia sebagai negara yang menghargai kepelbagaian agama termasuk keragaman partai politik.

Salah satu cara menghargai dan merawat keragaman agama dan politik tersebut adalah membuka ruang yang luas dan lebar tentang pelbagai macam ideologi politik atau ideologi kenegaraan yang tetap dipayungi dengan semangat Kesatuan Negara Republik Indonesia, bukan dalam semangat mengganti dasar negara dan merombak Indonesia menjadi negara federasi, sekalipun usaha-usaha seperti ini pernah coba dilakukan. Tetapi akhirnya juga tidak berlanjut sebab tidak sesuai dengan kultur nusantara.

Indonesia yang pluralistik dalam naungan Negara Kesatuan Republik Indonesia (NKRI) dengan pilar Pembukaan UndangUndang Dasar 1945, Pancasila, Bhinneka Tunggal Ika, dan NKRI sebenarnya telah final sebagai sebuah "maklumat politik", tetapi seringkali digosok-gosok oleh sekelompok kecil kelompok masyarakat dengan dalih perlunya uji coba dasar negara dan ideologi lain dalam bernegara. Dalam kondisi yang serba compang-camping dalam hal penegakan hukum, pemenuhan kesejahteraan masyarakat, pendidikan yang tidak merata, politik yang nyaris tidak beradab, politik tanpa fatsoen politik dan bernegara tanpa negarawan memang kemungkinan adanya penggerogotan dan upaya mencari dasar negara dan ideologi negara yang lain dimungkinkan terjadi.

Akan tetapi, upaya-upaya penggantian dasar negara dan ideologi negara akan menghilang dengan sendirinya ketika para pemegang kendali politik negara ini berjibaku dalam memperjuangkan kesejahteraan masyarakat, meningkatkan mutu dan perluasan jangkauan akses pendidikan pada 
seluruh warga negara, penegakan hukum yang baik, berpolitik yang santun dan bermartabat, maka upaya-upaya despotik mengubah dasar negara dan ideologi kenegaraan akan lenyap bahkan hancur dengan sendirinya. Oleh sebab itu, dapat dikatakan bila negara gagal memberikan pelayanan yang maksimal pada masyarakat, maka kemunculan gerakan-gerakan yang selama ini dianggap "separatis" dan makar akan terus berlangsung, sekalipun agak sulit besar, tetapi mengganggu.

Oleh sebab itu, negara dan para pembawa kendali kebijakan politik negara tidak boleh menggandaikan negara ini kepada kekuatan-kekuatan negara lain, hanya untuk mendapatkan "citra politik" internasional yang bermartabat, dianggap demokratis, mengikuti perubahan dan mendapatkan hutang. Para punggawa ke- bijakan negara harus berjibaku dalam koridor memperjuangkan hak dan martabat bangsanya sekalipun harus berhadapan dengan kekuatan senjata negara lain yang suka main-main dengan Negara Kesatuan Republik Indonesia.

Belajarlah kepada Martin Luther King, Jr dan Malcolm X dalam memperjuangkan hak-hak warga negara kulit hitam yang selama ratusan tahun didiskriminasi oleh kebijakan rezim politik Amerika, akhirnya juga mendapatkan haknya sehingga ketika Barack Obama menjadi presiden pertama dari bangsa kulit hitam, dunia menaruh harapan akan terjadi perubahan dalam perilaku politik negeri Paman Sam yang adidaya. Bagaimana dengan Indonesia, beranikan melakukan perubahan politik yang dimulai dari dirinya sendiri, bukan karena didikte negara lain. 